\title{
Assessing the Impact of High-Technology Exports on the Growth of the Turkish Economy
}

\author{
Emrah SOFUOĞLU' ${ }^{\oplus}$, Oktay KIZILKAYA ${ }^{1} \oplus$, Emrah KOÇAK ${ }^{2} \odot$
}

\begin{abstract}
High technology product export is emerging as one of the issues that economists have discussed frequently in recent years. Increasing the high-tech product export performance provides a competitive advantage in international trade for countries. To this extent, this study aims to determine the impact of high technology product export on economic growth for Turkey over the period 1990-2019. For the empirical analysis, Hatemi-J (2008), Gregory and Hansen (1996) Fully Modified Ordinary Least Squares (FMOLS), DOLS, and Canonical cointegration regression (CCR) methods are utilized. According to the Hatemi-J cointegration test, there is a long-term relationship between high-technology product export, fixed capital formation, and economic growth, yet a structural break was detected for 2008. In addition, the Gregory and Hansen test result also confirms the cointegration relationship under structural breaks for 2003 and 2006. FMOLS, DOLS, and CCR long-term coefficient test results indicate that high technology product export positively impacts economic growth. The fundamental policy recommendation of this study is to increase financial resources to boost high-tech exports and thus economic growth.
\end{abstract}

Keywords: High technology product export, Economic growth, Fixed capital formation, Structural break cointegration, Hatemi-J cointegration Jel Classification: F43, 014, 047
'Dr., Ahi Evran University, Faculty of Economics and Administrative Sciences, Department of Economics, Kırşehir, Turkey

${ }^{2}$ Assoc. Prof., Ahi Evran University, Faculty of Economics and Administrative Sciences, Department of Economics, Kırşehir, Turkey ${ }^{3}$ Assoc. Prof., Erciyes University, Faculty of Economics and Administrative Sciences, Department of Economics, Kayseri, Turkey

ORCID: E.S. 0000-0001-7716-1599;

O.K. 000-0002-3830-9412

E.K. 000-0002-5889-3126

\section{Corresponding author:} Emrah SOFUOĞLU

Ahi Evran University, Faculty of Economics and Administrative Sciences, Department of

Economics, Kırşehir, Turkey

E-mail:

emrahsofuoglu@gmail.com

\section{Submitted: 10.06 .2021 \\ Revision Requested: 25.11.2021}

Accepted: 10.01.2022

Citation: Sofuoglu, E., Kizilkaya, O., \& Kocak, E. (2022). Assessing the Impact of hightechnology exports on the growth of the Turkish economy. iktisat Politikası Araştırmaları Dergisi - Journal of Economic Policy Researches, 9(1), 205-229.

https://doi.org/10.26650/JEPR950483 


\section{Introduction}

Economic development depends on many factors such as natural resources, capital formation, human resources, technological development, and socio-political environment. However, technological development is considered as one of the most important factors among these indicators since it provides countries to be able to produce technology and have advanced technology sectors (Grossman \& Helpman, 1989; Hobday et al., 2001; Gani, 2009; Frietsch et al., 2014; Usman, 2017; Ekananda \& Parlinggoman, 2017). Das (1998) clarifies the development process for each country as follows: i) product composition of exports will be transferred from intensive natural resources to unskilled labor in the first stage, ii) to physical and human capital-intensive exports in the second stage, and iii) technology and information centered exports in the third stage. Countries that produce and export high-tech materials display fast and sustainable growth performance. Kula (2003) emphasized that countries that want to gain a competitive advantage in international markets should increase the share of high-tech products in total production. Gani (2009), on the other hand, attributes economic development processes to improve the technological capabilities and technological investments and make improvements in this field.

The World Bank defines high-tech products as high R\&D intensity, such as aviation, defense, computers, pharmaceuticals, scientific equipment, and electrical products. Gani (2009) includes information technology products to this definition, such as electronic data processing equipment, software, electronic components, and telecommunications equipment. These products may be considered as an essential determinant of economic growth such as innovation, patents and R\&D (Bilbao-Osorio \& Rodríguez-Pose, 2004; Atun et al., 2007; Güloğlu et al., 2012; Kızılkaya \& Koçak, 2016). In countries producing and exporting products with significant technology, the high value-added and competitive trade model provides a comparative advantage as a driving force for economic growth.

Technology-producing countries may increase their output and have the opportunity to make their economic growth sustainable. However, some countries fall behind developed countries due to the lack of high-tech production and face development problems (Bilgin \& Şahbaz, 2009). Therefore, developing countries need to encourage high-tech production to reach higher growth rates (Kizllkaya et al., 2017). One of the policies to be implemented is to increase the R \& D investments, which lead to the creation of high-tech products (Liu \& Lin, 2005). As a developing country, Turkey should take the necessary steps in high technology to achieve sustainable economic performance.

Resource efficiency is essential for a country that prefers an export-based growth model. Resource efficiency, suitable investment environment, and technological developments 
make high-tech investments easier. With the globalization process, competition between countries has increased. In this context, countries' comparative advantages in the international market depending on three situations. The first is to specialize in the production of high-tech goods, and the second is to improve product quality with technology, and the third is to reduce costs (Kizilkaya et al., 2017). In this respect, R\&D expenditures and patent applications, considered among the technological development indicators, are essential to gain an advantage in the market.

As a developing country, Turkey may increase the share of high-tech exports in economic growth if the necessary technological and scientific infrastructure is established and legal regulations are implemented. Therefore, the motivation of this study is to examine the development of high technology export in Turkey and to analyze the long-term cointegration relationship between high technology export and economic growth under structural breaks over the period 1990-2019. The plan of the study is as follows: the theoretical background of high-tech exports is provided, and then Turkey's high-tech product export performance is discussed in the first section. Next, section presents the empirical literature. Then, the data, model, and method are introduced in Section 3, and empirical findings are reported in Section 4. Finally, in the conclusion part, empirical results are discussed, and some policy recommendations are suggested.

\subsection{Theoretical Background of Technology and Economic Development}

After the industrial revolution, many economists have emphasized that technological development is one of the preconditions for economic growth. Classical, Marxist, and NeoClassical economists also argue that technological developments are essential in the growth process. Smith (1776) thought that the division of labor affects capital accumulation. Increased specialization thanks to the division of labor increases capital accumulation and productivity. According to Smith (1776), with the increase in production and productivity, better machines should be built, and technology should be advanced to ensure the continuity of this situation. Ricardo (1817) states that technological development constantly shifts the total output upwards. Marx (1867) argues that with the theory of surplus-value, capital owners increase the capital factors in production and choose capital-intense production techniques to increase labor productivity. Marx (1867), with this theory, inspired Schumpeter (1966) on technological innovation. Schumpeter (1966) emphasizes that growth should be analyzed in the context of innovations, technological competition, and technological advances with the thesis of creative destruction. However, Keynes (1937) neglected technological developments (Hiç, 1998, pp. 19-20; Berber, 2006, pp. 75-77; Taban, 2011, pp. 44-45; Tiryakioğlu, 2011, pp. 172-173). 
Solow's (1956) model, one of the neoclassical theories, is based on technological developments increasing capital and labor productivity. According to this model, it is possible to produce more output thanks to technology by using existing production factors. According to the "Solow surplus" model, the unexplained portion of economic growth, except labor and capital increase, is technological development. The convergence hypothesis, which is one of the main implications of the Solow model, is based on the assumption that technological change is external and constant between countries. Accordingly, per capita output levels of countries will approach each other, and the development differences will automatically disappear in the long term.

On the other hand, according to Barro (1991) and Romer (1994), the assumption that technology is external and stable does not valid for national economies. Barro (1991) argues that conditional convergence may be possible, but poor countries must have the same level of technology to grow faster than rich countries. According to Barro (1991), poor countries with low capital to labor ratios have high marginal capital products, and therefore they tend to grow more. However, Krugman (2000) disagrees that the factor bias of technical change is only unimportant where such a change shows up in a small open economy (in contrast to an economy that can affect world prices) and where technical change occurs only in that economy (instead of coinciding in other economies). Therefore, Krugman (2000) emphasized that factor bias is important, as the real situation is not seen in both cases.

Studies such as Romer (1986), Lucas (1988), Grossman and Helpman (1989), Barro (1991), Aghion and Howitt (1992) proposed the assumption that technological development is endogenous and named as internal growth theories in the literature. Technological developments resulting from $\mathrm{R} \& \mathrm{D}$ activities, information technologies, and human capital are the essential elements of internal growth theories. These theories are based on the "learning by doing" thesis of Kenneth Arrow's (1962) led by Paul Romer and Robert Lucas towards the end of the 1980s. Arrow (1962) argues that an increase in information generation contributes to the economy more than the firm revenues through distribution and learning by doing. Based on the concept of learning by doing, Romer (1986) states that as a by-product, know-how is used as a kind of input in production and investment processes and provides cheap-cost and high-quality production. Besides, Romer (1986, 1990) and Lucas (1988) stated that (i) technical knowledge positively affects production processes by creating externalities in the economy, (ii) technological knowledge increases as investments increase in the economy, (iii) R\&D growth is a driving force for the economy, (iv) advances in R \& D activities create new products and new production processes, and v) these innovations are used by other companies in the sector and create a spillover effect. Posner (1961), on the other hand, examined the effect of technology on trade and introduced the concept of the "imitation gap" which explains the effect of imitation and innovation on trade. Accordingly, 
the exporting country first renews its technology for internal trade and then has an absolute competitive advantage in the product. According to another approach developed by Vernon (1966), capital-intensive and technologically sophisticated innovations are mostly being developed for the domestic market in the United States. Vernon (1966) proposed the Product Life Cycle model (PLC) theory, which is seen as an extension and generalized form of Technology Deficit Theory. This theory presents the dynamic theory of comparative advantages over information-intensive products. According to the PLC, new products go through many stages during their development, and comparative advantage changes throughout the product periods.

Grossman and Helpman (1989) argue that technological innovations arise due to rational behaviors of entrepreneurs based on profit expectations. He believes that productivity increases resulting from technological innovations are the source of economic growth in the long run. According to Grossman and Helpman (1989), growth occurs in two ways: (i) improvements in the quality of goods and services and (ii) product diversity as a result of the production of new technologies in the R\&D sector. In this way, countries can increase their export volumes by gaining comparative advantage in foreign trade with the diversity of products from technological developments. Barro (1991) states that a better-educated labor force plays a vital role in adapting and producing new technologies.

On the other hand, based on Schumpeter's creative destruction hypothesis, Aghion and Howitt (1992) contributed significantly to the impact of technological developments on growth. According to Aghion and Howitt (1992), innovation-producing R\&D activities emerge from competition between firms. Similarly, Grossman and Helpman (1991), Hanel (2000), Wakelin (2001), and Yeldan (2010) point out that technological developments and investments are important factors in the growth performance.

\subsection{The Development of High Technology Export in Turkey}

Import substitution is a strategy under the trade policy that abolishes the import of foreign products and encourages production in the domestic market. Turkey abandoned the importsubstitution production model after the 1980s and preferred an export-based outward-oriented economy. R\&D spendings and the number of patents have increased significantly in recent years. However, the amount is still low compared to other countries. As seen in Figure 1, the share of R\&D expenditures in GDP was $0,52 \%$ in 2002, 0,85\% in 2011 and finally $0,96 \%$ in 2017. The OECD average was \%2,24 in 2002, \%2,39 in 2011 and \%2,50 in 2017 (World Bank, 2021). Another interesting point is that the share of public resources to the technological developments increased (World Bank, 2018); however, the rate of R\&D expenditures in GDP was still below 1\% over 1996-2017. A similar situation is observed for patent applications. 
Figure 1. R \& D Expenditures (\%GDP) and Patent Applications in Turkey (1996-2017)

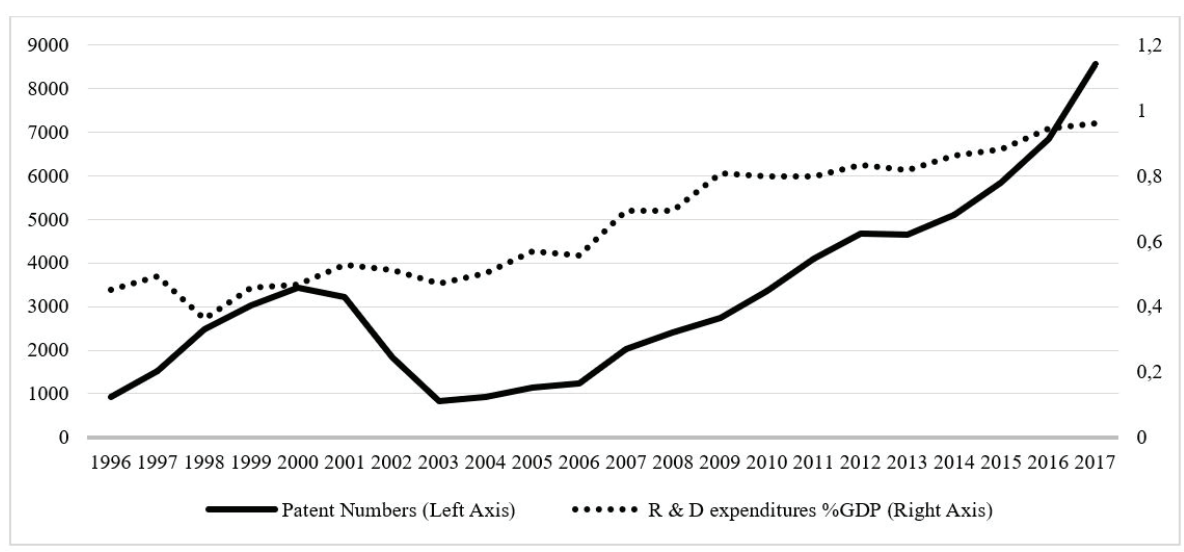

Source: World Bank, 2021

The export performance has a substantial impact on economic growth. This is because countries with a competitive advantage in the international markets can increase their export volumes.

According to the report published by World Bank (2014), despite high export growth in the last decade, exports were unable to be the main driving force of economic growth in Turkey. Exports in GDP were 20\% in the $1998-2000$ period and increased to $23 \%$ in 2009 2011. The share of exports in GDP increased by $10 \%$ in European countries, $11 \%$ in India, and $9 \%$ in China in the same period. In the related report, the reason is as follows. i) Turkey has specialized in medium-tech sectors with relatively slow-growing global demand. ii) There has been no significant progress in exporting high-tech products. iii) Turkey does not have a comparative advantage in high-tech products. iv) Turkey has diversified its export markets and product range but could not enter the high-tech field.

Turkey's high tech-export has been increasing in general despite some decrease since 1980, especially after the 2008 financial crisis. According to Figure 2, Turkey's high-tech exports increased by more than 50\%. High-tech exports, which were 1.89 billion dollars in 2007, reached 4.3 billion dollars in 2019. A similar increase is observed in the share of hightech exports in the manufacturing industry. It rose from $1.89 \%$ in 2007 to $3.04 \%$ in 2019 . Although Turkey has recently made significant progress in high technology, it ranks far behind many countries. 
Figure 2. High-Tech Product Export in Turkey in 2007-2019 (\% of Manufacturing, million \$)

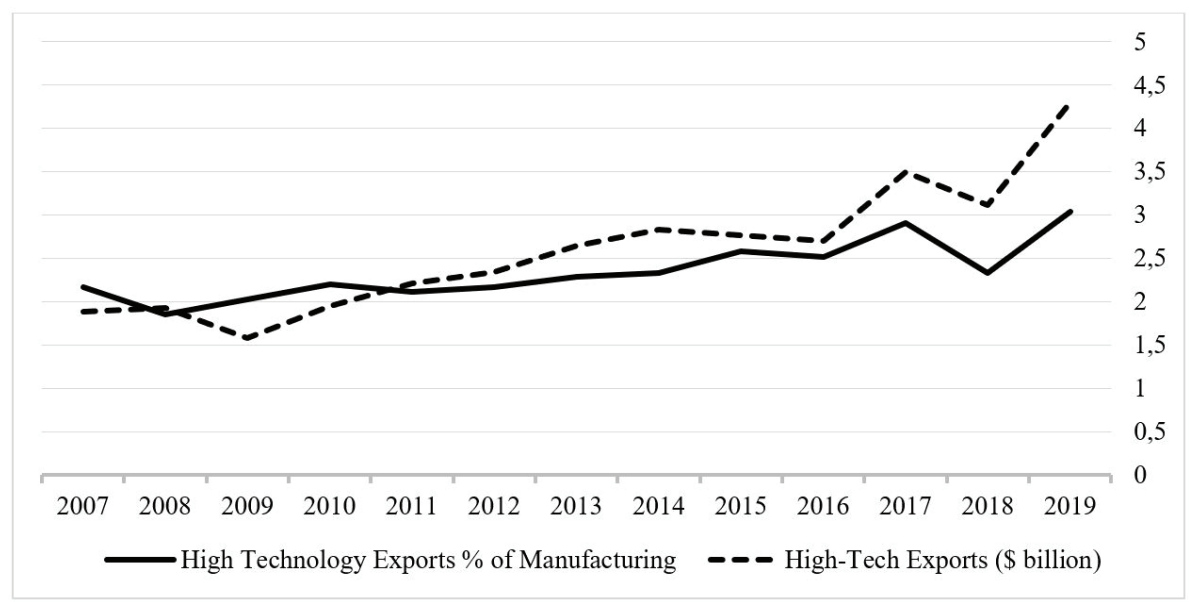

Source: World Bank, 2021

According to World Bank (2021), while the share of high technology exports in the manufacturing industry in the Euro area is 5.89 on average, it is 3.03 in Turkey. In addition, among the BRIC-T (Brazil, Russia, India, China, and Turkey) countries, Turkey was ranked last in 2019 in terms of high-technology product export.

\section{Literature Survey}

Many technological indicators explain the relationship between technological development and economic growth in the literature. In this section, the studies in the literature are categorized into three groups. First of all, studies focusing on R\&D expenditures and economic growth are examined. The second group of studies discusses the relationship between innovation, patents, information communication technologies, and economic growth. Finally, studies that analyze the relationship between high-tech exports and economic growth in the third group are presented.

The first group of studies focuses on $R \& D$ spendings regarding the positive impacts on economic growth. Lichtenberg (1993) investigated the relationship between R\&D expenditures financed by the private and public sector and economic development in 74 countries in 1964-1989 by panel least squares (OLS) method. According to the results, while private sector R\&D expenditures affect growth positively, there is no significant relationship between public sector R\&D expenditures and economic growth. Freire-Seren (1999) stated that R\&D expenditures positively impacted domestic income in 21 OECD countries during the 1965-1990 period. Sylwester (2001) analyzed the relationship between R\&D and 
economic growth in G7 and 20 OECD countries over 1981-1996. In this study, the effect of $\mathrm{R} \& \mathrm{D}$ on economic growth was positive for G7 countries, but no significant relationship was found for OECD countries. Zachariadis (2004) concluded that R\&D expenditures and investment positively affected the output in the 10 OECD countries for 1971-1995. On the other hand, Samimi and Alerasoul (2009) found a negative and insignificant relationship between R\&D expenditures and economic growth in 30 developing countries in 2000-2006. The reason for that is $R \& D$ expenditures are low among the total spending in developing countries.

Gülmez and Yardımcığlu (2012) investigated the relationship between R\&D spending and economic growth in 21 OECD countries during 1990-2010 with panel cointegration and panel causality analysis. The study found that the increase in R\&D spendings provides a relative increase in economic growth, and there is a feedback relationship due to the bidirectional causality between the variables. Gülmez and Akpolat (2014) investigated the relationship between $\mathrm{R} \& \mathrm{D}$ expenditures, patent numbers, and growth by using the GMM (Generalized Method of Moments) method between 2000-2010 for Turkey and 15 E.U. countries. They concluded that R\&D and patents positively affect economic growth but that $\mathrm{R} \& \mathrm{D}$ expenditures are four times more effective than patents on economic growth.

Doruk and Söylemezoğlu (2014) investigated the relationship between R\&D and GDP per capita in 22 developing countries in 2000-2007 with GMM and system GMM methods. As a result of the study, R\&D expenditures positively affect GDP per capita. Inekwe (2015) analyzed the relationship between R\&D expenditures and economic growth using the GMM method for 66 selected developing countries. In the study, the impact of R\&D spending on economic growth was low in the low-income countries, while this effect was positive in the upper and middle-income countries.

Liu and Xia (2018) analyzed the relationship between R\&D investment, technological innovation, and economic growth for the Chinese economy with the Vector Autoregression (VAR) model for 1995-2016. Empirical analysis revealed that R\&D investments, technological innovations, and economic growth have slowed down in China in recent years, and this situation does not provide sufficient bases for economic development. The study concluded that the Chinese economy should improve the interaction between $R \& D$ investments, technological innovations, and economic growth. Dinçer et al. (2019) aimed to evaluate the effects of research and development on economic growth, exports, and unemployment in developing economies. In this context, considering the E7 countries, the annual data of these variables for the period 1996-2016 were tested using Dumitrescu Hurlin panel causality analysis. It is concluded that $R \& D$ expenditures positively affect export for the countries. 
For this reason, it is suggested that developing economies should take the necessary measures to increase their research and development investments in order to reach higher export rates. Nair et al. (2020) analyzed the relationship between R\&D expenditures, information and communication technology, and economic growth for OECD countries over the period 1961-2018 by using a panel vector autoregressive model. They found that infrastructure development in high-tech products and information and communication technology positively contributes to economic growth in the long run.

The second group of studies focuses on the relationship between innovation, patents, and economic growth indicators. For example, Hasan and Tucci (2010) examined the linkage between innovation and economic growth in 58 countries from 1980-2003. The authors considered patent applications as an indicator of innovation. As a result of the study, it is stated that an increase in patents leads to higher economic growth. Güloğlu and Tekin (2012) investigated the relationship between $\mathrm{R} \& \mathrm{D}$ expenditures, patents, and economic growth in high-income OECD countries from 1991-2007 using the panel vector autoregressive (VAR) model and GMM methods. As a result, a unidirectional causal relationship was determined from R\&D to patent and from patent to economic growth. Amaghouss and Ibourk (2013) examined the relationship between entrepreneurship, innovation, and economic growth in 19 OECD countries for 2001-2009 by using the panel data method. The results indicate that both entrepreneurship activities affect economic growth positively. Finally, the study underlines that a quality institutional environment is an essential incentive for entrepreneurship and innovation. Hu and Png (2013) examined the relationship between patent rights, factor accumulation, and efficiency for 54 manufacturing industries in 72 countries in 1981-2000. They concluded that patent rights are associated with rapid growth. Myszczyszyn (2020) investigated the long-run relationship between several patents, including valuable patents and economic growth, using the Johansen cointegration test for Germany over 1872-1913. Empirical findings indicate a long-term relationship between the variables.

On the other hand, Oliner and Sichel (1994) discussed the relationship between technology and economic growth in the context of information and communication technologies (ICT). The study concluded that ICT had a vital role in economic growth in the USA between 1970-2012. Furthermore, Pohjola (2000) examined the relationship between investment and economic growth in 39 countries for 1980-1995. According to the empirical results, there is no significant relationship between information technology investment and economic growth. Finally, Colecchia and Schreyer (2001) investigated the impact of capital stock in information and communication technology on economic growth through the growth accounting approach in 9 OECD countries for 1980-2000. They found that technological investments positively affect economic growth and this effect varies depending on the differences in the countries' economic structures. 
Hitt and Brynjolfsson (2002) concluded that the increase in computer use for 527 US firms in 1987-1994 positively impacts productivity and growth in the long run. Finally, Pazarlığlu and Gürler (2007) examined the relationship between telecommunication infrastructure investments, economic growth, and economic efficiency in E.U. countries from 1990-2004. The result of the research indicates that the effect of telecommunication infrastructure investments on GDP per capita is significant and positive. Samimi (2010) investigated the relationship between Digital Opportunity Index (DOI) and economic growth as an ICT indicator in 30 developing countries for 2001-2006 with panel data analysis. Findings indicate a positive relationship between DOI and economic growth in some countries.

Farhadi and Ismail (2011) examined the relationship between ICT and economic growth by expanding country groups for OECD, BRICs, and NICs countries in 1990-2008. As a result, ICT has a positive effect on economic growth. Farhadi and Fooladi (2011) state that the use of information and communication technologies in 159 countries positively impacts growth for 2000-2009; however, this effect increases as income rises. Lee (2011) investigates the relationship between ICT and growth in Japan, South Korea, and China in 1975-2009 by using time series analysis. As a result, long-term relation between ICT and economic growth is detected only for South Korea.

$\mathrm{Vu}$ (2013) tests the possible effects of information and communication technologies on economic growth in Singapore during the 1990-2008 period. Three crucial findings are obtained. First, a positive relationship is found between the intensive use of ICT and labor productivity. Second, ICT contributes approximately $1 \%$ to Singapore's growth rate. Third, the ICT manufacturing sector also contributes to economic growth rates in Singapore. Appiah-Otto and Song (2021) analyzed the relationship between ICT and economic growth by comparing rich and poor countries for 2002-2017. Analysis results show a positive relationship between ICT and economic growth in two groups. However, poor countries seem to benefit more from ICT than rich countries.

R\&D, innovation, patents, and ICT are essential for technological development. However, research on high-tech product exports in the literature is limited. In this context, a small number of third group studies examined the relationship between high-tech product exports and economic growth. In this way, Cuaresma and Wörz (2005) analyze the impact of high technology exports on productivity for 45 countries from 1981-1997. According to the study, high-tech exports positively impact economic growth while low-tech exports negatively impact. According to the findings, high technology product exports lead to increased productivity between domestic and foreign competition. Gani (2009) analyzes whether high-tech exports determine economic growth in countries with higher technological 
achievements. The study results show that high technology exports have a strong and positive impact on economic growth per capita. In order to benefit from technology, technological capabilities should be developed in the fields of technology creation, technological improvement, and product development. These developments also suggest R\&D and human capital investments and more free-market policies.

Mccann (2007) employs panel data analysis for 1980-2000 to examine the impact of export structure on economic development. According to McCann (2007), countries should diversify their exports from low technology to high technology products for economic development. Arica and Ataklı (2010) test the effect of the export of high-tech products and patent applications on economic growth in 21 OECD countries for 1989-2009 using the panel data method. As a result, it is determined that high technology product exports and patent applications positively impact economic growth.

Kızılkaya and Koçak (2016) analyzed the relationship between high-tech product exports and economic growth in 18 high middle-income countries from 1996-2015 by utilizing panel cointegration and causality analysis. As a result of the research, it is determined that high-tech product export positively affects economic growth in the short and long run. Ustabaş and Ersin (2016) analyze the relationship between high-tech exports and GDP per capita for 1989-2014 using structural unit root tests and Johansen cointegration methods for Turkey and South Korea. Findings show that while high-tech exports positively affect both in the short and long term in South Korea, this result is valid in the short term for Turkey. According to the results, Turkey needs to increase R\&D and human capital investment for high-tech exports and economic growth. Telatar et al. (2016) analyze the impact of high-tech exports on economic growth over the period 1996:01-2015:03. In this study, technology products are divided into low, medium, and high subgroups. According to Engle-Granger cointegration and Granger causality tests, low- and medium-technology exports positively and significantly affect the Turkish economy. Granger causality findings indicate a strong relationship between medium and high-tech product exports and economic growth. Besides, Turkey needs to produce and export high-tech products to reach sustainable development. Abidi (2020) found a positive relationship between high-technology export and economic growth in Togo for 2008-2017 by using a regression model. Canbay (2020) reached a similar result for Turkey over 1989-2016 by using ARDL bound testing.

Ekananda and Parlinggoman (2017) analyzed 50 countries to observe the impact of foreign direct investment and high technology exports on GDP. Two groups of countries are examined as countries with high and low technology exports in the study. The results show that positive changes in high technology exports positively to both countries. The study's findings show that high-tech exports affect GDP through productivity for both country 
groups. Usman (2017) examines the effect of high-tech product exports on Pakistan's economic growth for 1995-2014 by using the Least Squares (OLS) method. In the analysis, it is concluded that high-tech exports positively affect economic growth. As a developing country, Pakistan's high-tech product export performance is lower than other countries due to the lack of $R \& D$ investments.

Algan et al. (2017) examine the relationship between technological progress and economic growth indicators in Turkey for 1996-2015 by using the Granger causality test. In this research, the share of high technology exports, patent applications, and R\&D expenditures in GDP represent technological developments. According to the results, there is a unidirectional causality relationship from $\mathrm{R} \& \mathrm{D}$ expenditures and high-tech product exports to GDP per capita in the short term. It is concluded that there is a positive relationship between GDP per capita, R\&D expenditures, and patent applications in the long term. However, high-tech exports affect GDP per capita negatively. Kabaklarlı et al. (2018) analyzed the long-term relationship between high technology exports and economic growth in selected OECD countries from 1989-2015 by using the panel cointegration method. The empirical results show that an improvement in patent applications and foreign direct investment is a determining factor in rising high technology exports in selected OECD countries. However, economic growth and foreign investment play a negative role in increasing high technology exports of the countries. Şahin (2019) used Granger causality analysis to investigate the impact of high-tech exports on economic growth in Turkey for the period 1989-2017. As a result of the causality analysis in the study, it has been determined that there is a causal relationship between high technology exports and economic growth.

Literature summary shows that high-tech product export plays an important role in economic development in general. In the literature, technological development indicators such as R\&D, innovation, developments in information technologies become prominent for high-tech product export and economic growth. According to the first group of studies, it is generally seen that R\&D expenditures have a positive effect on economic growth (Lichtenberg, 1993; Freire-Seren, 1999; Sylwester, 2001; Zachariadis, 2004; Gülmez \& Yarımoğlu, 2012; Gülmez \& Akpolat, 2014; Doruk \& Söylemezoğlu, 2014; Scott et al., 2017; Nair et al., 2020). However, Samimi and Alerasoul (2009) attributed the negative impact of R\&D expenditures on economic growth to the low share of R\&D expenditures in total expenditures in developing countries. Samimi and Alerasoul (2009) stated that R\&D expenditures negatively affected economic growth and attributed this to the low share of R\&D expenditures in total expenditures in developing countries. In parallel, Inekwe (2015) found that R\&D expenditures on economic growth are lower in low-income countries and higher in upper and middle-income countries. General results of the second group of studies show that the increase in the number of patents (Hasan \& Tucci, 2010; Hu \& Png, 2013; 
Myszczyszyn, 2020) and innovation (Amaghouss \& Ibourk, 2013) result in economic growth, and there is a causal relationship from patent to economic growth ( Güloğlu \& Tekin, 2012). High technology investments and ICT are also factors that positively affect economic growth (Oliner \& Sichel, 1994; Colecchia \& Schreyer, 2001; Hitt \& Brynjolfsson, 2002; Pazarlığlu \& Gürler, 2007; Sincere 2010; Farhadi \& Ismail, 2011; Farhadi \& Fooladi, 2011; Vu, 2013; Appiah-Otto \& Song, 2021). According to the third group studies which focus on high-tech product export and economic growth, Cuaresma and Wörz (2005), Gani (2009), McCann (2007), Arıca and Ataklı (2010), Kızılkaya and Koçak (2016), Ustabaş and Ersin (2016), Telatar et al. (2016), Usman (2017), Abidi (2020), Canbay (2020) have provided evidence for the importance of high technology in the economic growth process. According to Cuaresma and Wörz (2005), high-tech product exports lead to productivity differences between domestic and foreign competition. Gani (2009) revealed the necessity of developing technological capabilities in technology creation, technological knowledge, and product development. McCann (2007), on the other hand, stated that economies should diversify their export structures towards high-tech products.

\section{Methodology and Findings}

\subsection{Model and Data Set}

In this study, the following model will be estimated to reveal the impact of high-tech product export on economic growth.

$$
\mathrm{LNGDP}_{\mathrm{t}}=\beta_{0}+\beta_{1} \mathrm{LNHT}_{\mathrm{t}}+\beta_{2} \mathrm{LNFIX}_{\mathrm{t}}+\varepsilon_{\mathrm{t}}
$$

In model (1), t, $\beta_{0}$, and $\varepsilon$ represent the sample period, constant term, and error term. $\beta_{1}$ and $\beta_{2}$ are the coefficients of elasticity that illustrate the impact of high-tech exports and fixed capital formation on economic growth. Fix capital formation is added to the model as a proxy variable. Economic growth (LNGDP) represents GDP constant prices. High-tech product export (LNHT) represents high technology product export expenditure. Finally, fix capital formation development (LNFIX) represents the gross fixed capital formation (U.S. dollar at constant prices in 2010). The research data covering 1990-2019 is annual and obtained from World Bank Development Indicators and OECDstat. The data was converted to a natural logarithmic value. Figure 3 shows the time series. Accordingly, an uptrend is observed in all series after the 2000s except for the 2008 financial crisis. 


\section{Figure 3. Time Series Variations}

LNGDP

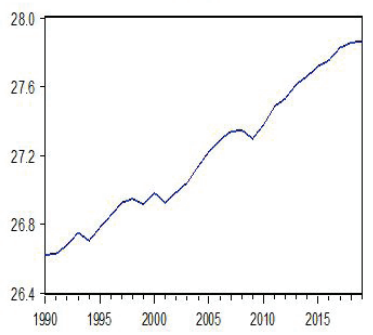

LNHT

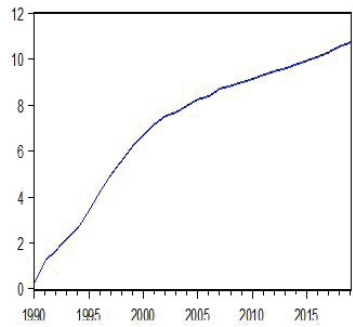

LNFIX

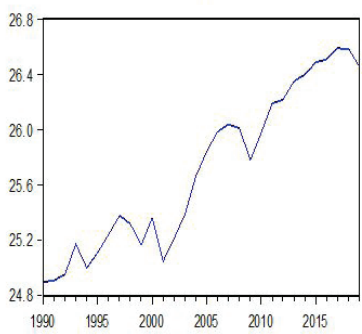

Table 1 shows the descriptive statistics and correlation matrix of the data set. Accordingly, the mean, median, minimum, maximum, and standard error values are closely spaced. Therefore, the data are suitable for analysis. Variations, descriptive statistics, and correlation matrix suggest some preliminary information about the relationship among the variables. According to the correlation relationship, there is a positive relationship between high technology product exports, fixed capital formation, and economic growth.

Table 1: Descriptive Statistics and Correlation Matrix

\begin{tabular}{lccc}
\hline Descriptive Statistics & LNGDP & LNHT & LNFIX \\
\hline Mean & 27,20 & 7,05 & 25,71 \\
Median & 27,18 & 8,11 & 25,72 \\
Maximum & 27,86 & 10,74 & 26,59 \\
Minimum & 26,62 & 0,24 & 24,90 \\
Std. Dev. & 0,40 & 3,11 & 0,58 \\
Observations & 30 & 30 & 30 \\
\hline
\end{tabular}

\subsection{Method}

In econometric studies, it is necessary to investigate whether the series of related variables are constant over time; in other words, it is stationary. For this reason, the unit root tests developed by Dickey and Fuller (1981) and Phillips and Perron (1988) will be used. However, unit root test results frequently indicate that the series values are not stationary at level value but stationary at first differences. In this case, a linear combination of cointegration relationships between the series should be investigated. Cointegration methods developed by Engle and Granger (1987), Johansen (1988), and Johansen and Juselius (1990) are used extensively in the literature. In addition, structural breaks will be considered to reach more reliable findings.

The cointegration method developed by Gregory and Hansen (1996) considers structural breaks. However, this test finds only one break. On the other hand, the cointegration method developed by Hatemi-J (2008) considers two breaks. 
Hatemi-J (2008) estimates a model as follows:

$$
y_{t}=\alpha_{0}+\alpha_{1} D_{1 t}+\beta_{0}^{\prime} x_{t}+\beta_{1}^{\prime} D_{1 t} x_{t}+u_{t}
$$

In model (2), $\mathrm{y}$ and $\mathrm{x}$ represent a dependent variable and explanatory, while $\mathrm{D}_{1 \mathrm{t}}$ and $\mathrm{D}_{2 \mathrm{t}}$ show structural breaks. Hatemi-J (2008) predicts three models using the $\mathrm{Z} \alpha$ and $\mathrm{Zt}$ tests developed by Phillips (1987) and Augmented Dickey-Fuller test statistics suggested by Engle ve Granger (1987) to test the null hypothesis that there is no cointegration. The first of these models is defined as Model 2 (C) level shift, the second is Model 3 (C / T) level and trend shift, and the third is Model 4 (C / S) regime shift. The decision is made about the null hypothesis for all three models by comparing the relevant test statistics with critical values. If the null hypothesis is rejected according to the test results, a cointegration relationship between the variables is confirmed.

After the cointegration relationship, the next stage is detected to estimate the coefficients for the long-term relationship. For this, Philips and Hansen (1990) fully modified least squares (FMOLS), Park (1992) Canonical cointegration regression (CCR), and Stock and Watson (1993) dynamic least squares method (DOLS) will be used. However, if the sample is small for the analysis, traditional least squares (OLS) estimators make biased estimates, and the problem of endogeneity arises. In this case, alternative estimation methods that produce unbiased results in small samples should be employed (Montalvo 1995). Therefore, this study will follow the Dynamic OLS (DOLS) method developed by Stock and Watson (1993) for regression estimation, which produces robust results in small samples.

\subsection{Empirical Findings}

Table 2 shows the unit root test results. According to the test results, all series are not stationary at level values. Therefore, the first differences of series are taken, and the unit root test is applied again. Accordingly, it is decided that the series are stationary at first differences. Therefore, all series used in the analysis are I (1).

Table 2: Unit Root Test Results

\begin{tabular}{|c|c|c|c|}
\hline Variables & & ADF test statistics & P.P. test statistics \\
\hline LNGDP & & $-2,49$ & $-2,53$ \\
\hline LNHT & & $-2,59$ & $-2,09$ \\
\hline LNFIX & & $-2,61$ & $-2,66$ \\
\hline$\Delta$ LNGDP & & $-5,30^{\mathrm{a}}$ & $-6,47^{\mathrm{a}}$ \\
\hline$\Delta \mathrm{LNHT}$ & & $-3,25^{b}$ & $-3,47^{b}$ \\
\hline$\triangle \mathrm{LNFIX}$ & & $-5,45^{\mathrm{a}}$ & $-5,46^{a}$ \\
\hline \multirow[t]{3}{*}{ Critical Values } & $\% 1$ & $-4,34$ & $-4,32$ \\
\hline & $\% 5$ & $-3,59$ & $-3,58$ \\
\hline & $\% 10$ & $-3,23$ & $-3,23$ \\
\hline
\end{tabular}

Note: ${ }^{*} \Delta$ represents the first difference processor. ${ }^{a}$ shows statistical significance at $1 \%$ significance level. ${ }^{b}$ shows statistical significance at $10 \%$ significance level. 
Table 3 presents Hatemi-J (2008) cointegration test results. According to the ADF test statistics, the null hypothesis that no cointegration is rejected in Model 2, Model 3, and Model 4. However, according to $\mathrm{Z}_{\mathrm{t}}^{*}$ test statistics in all models, the null hypothesis cannot be rejected. Thus, it can be said that there is a long-term relationship between economic growth, high-tech exports, and fixed capital formation.

The break date is 2009 in three models. Other break dates (2008 and 2010) are not statistically significant. These results refer to the 2008 global financial crisis. The shocks in these periods are expected to affect high-technology export and economic growth. Therefore, the 2009 break date will be added to the long-term coefficient estimation model as a dummy variable.

Table 3: Hatemi-J (2008) Cointegration Test Results

\begin{tabular}{|c|c|c|c|}
\hline & $\begin{array}{c}\text { Hatemi-J }(\mathrm{C} / \mathrm{S})^{*} \\
\text { Model } 4\end{array}$ & $\begin{array}{c}\text { Hatemi-J }(\mathrm{C} / \mathrm{T})^{*} \\
\text { Model } 3\end{array}$ & $\begin{array}{c}\text { Hatemi-J }(\mathbf{C})^{*} \\
\text { Model } 2\end{array}$ \\
\hline \multicolumn{4}{|l|}{ ADF test } \\
\hline Optimal Lag & 2 & 2 & 2 \\
\hline t stat. & $-5,32$ & $-5,33$ & $-5,23$ \\
\hline First Break Point (ADF) & 0,60 & 0,60 & 0,56 \\
\hline Break Date & 2009 & 2009 & 2008 \\
\hline Second Break Point (ADF) & 0,60 & 0,60 & 0,63 \\
\hline Break Date & 2009 & 2009 & 2010 \\
\hline \multicolumn{4}{|l|}{ Phillips test } \\
\hline $\mathrm{Z}_{\mathrm{t}}^{*}$ & $-7,50^{\mathrm{a}}$ & $-7,51^{\mathrm{a}}$ & $-6,36^{\mathrm{c}}$ \\
\hline First Break Point $\left(Z_{t}^{*}\right)$ & 0,60 & 0,60 & 0,60 \\
\hline Break Date & 2009 & 2009 & 2009 \\
\hline Second Break Point $\left(Z_{t}^{*}\right)$ & 0,60 & 0,60 & 0,60 \\
\hline Break Date & 2009 & 2009 & 2009 \\
\hline $\mathrm{Z}_{\alpha}^{*}$ & $-38,64$ & $-37,87$ & $-34,88$ \\
\hline First Break Point $\left(\mathrm{Z}_{\alpha}{ }^{*}\right)$ & 0,56 & 0,63 & 0,63 \\
\hline Break Date & 2008 & 2010 & 2010 \\
\hline Second Break Point $\left(Z_{\alpha}{ }^{*}\right)$ & 0,56 & 0,63 & 0,63 \\
\hline Break Date & 2008 & 2010 & 2010 \\
\hline
\end{tabular}

Note: ${ }^{*}$ Critical values are obtained from the study carried out by Hatemi-J (2008). ${ }^{\mathrm{a}}$ shows statistical significance at $1 \%$ significance level. ${ }^{\mathrm{b}}$ shows statistical significance at $5 \%$ significance level. ${ }^{c}$ shows statistical significance at $10 \%$ significance level.

Table 4 shows the Gregory Hansen cointegration test results. This method tests the existence of a long-term relationship between the variables in three different models by considering one structural break. According to the results obtained from all three models, there is a long-term cointegration relationship between the variables. Structural break dates are 2003 in the $\mathrm{CC}$ and $\mathrm{C} / \mathrm{T}$ models and 2006 in the $\mathrm{C} / \mathrm{S}$ model. 
Table 4: Gregory Hansen Cointegration Test

\begin{tabular}{lccc}
\hline & $\begin{array}{c}\text { Model 2: } \\
\text { Level Shift (CC) }\end{array}$ & $\begin{array}{c}\text { Model 2: } \\
\text { Level Shift with Trend (C/T) }\end{array}$ & $\begin{array}{c}\text { Model 2: } \\
\text { Regimel Shift (C/S) }\end{array}$ \\
\hline \multicolumn{4}{c}{ ADF Procedure } \\
\hline t-stat & -2.99 & -3.44 & $-5.84^{\mathrm{b}}$ \\
Bag & 0.00 & 3 & 0.00 \\
\hline \multicolumn{5}{c}{} & 2003 & 2006 \\
\hline Za-stat & 2003 & PHILIPS Procedure \\
Za-break & $-18.33^{\mathrm{a}}$ & $-18.42^{\mathrm{a}}$ & $-30.25^{\mathrm{a}}$ \\
Zt-stat & 2003 & 2003 & 2006 \\
Zt-break & -3.04 & -3.32 & -5.91 \\
\hline
\end{tabular}

Note: ADF test statistic for CC: $1 \%(-5.44), 5 \%(-4.92)$ and $10 \%(-4.69)$; for C/T; $1 \%(-5.80), 5 \%(-5.29)$ and $10 \%(-5.03)$; for C/S:

$1 \%(-5.97), 5 \%(-5.50)$ and $10 \%(-5.23)$. ${ }^{\text {a }}$ shows statistical significance at $1 \%$ significance level. ${ }^{b}$ shows statistical significance at $5 \%$ significance level.

Table 5 shows the long-term coefficient estimation results. Again, the break date determined by the PP test in all models is considered, and the dummy variable in the model represents the year (2009).

(i) According to DOLS, FMOLS, and CCR results, the coefficients of high-tech exports and fixed capital formation on economic growth are positive and statistically significant. Therefore, high-technology exports and fixed capital formation affect economic growth positively in the long term.

(ii) According to all test results, the coefficient of the dummy variable (2009) is negative and statistically significant, which means the 2008 global financial crisis affected economic growth negatively in Turkey. The similarity of the empirical findings from all tests strengthens the reliability of the model.

Table 5: Long Term Coefficients (Dependent Variable: LNGDP)

\begin{tabular}{lcccccc}
\hline & \multicolumn{2}{c}{ DOLS } & \multicolumn{2}{c}{ FMOLS } & \multicolumn{2}{c}{ CCR } \\
\hline Variables & Coefficient & t stat & Coefficient & t stat & Coefficient & t stat \\
\hline LNHT & $0,02^{\mathrm{b}}$ & 2,46 & $0,02^{\mathrm{b}}$ & 2,77 & $0,03^{\mathrm{a}}$ & 3,06 \\
LNFIX & $0,59^{\mathrm{a}}$ & 12,32 & $0,58^{\mathrm{a}}$ & 18,13 & $0,58^{\mathrm{a}}$ & 13,03 \\
D1(2008) & $-0,11^{\mathrm{c}}$ & $-1,68$ & $-0,35^{\mathrm{a}}$ & $-6,68$ & $-0,18^{\mathrm{a}}$ & $-1,68$ \\
C & $11,99^{\mathrm{a}}$ & 10,31 & $12,13^{\mathrm{a}}$ & 15,09 & $12,20^{\mathrm{a}}$ & 11,21 \\
\hline
\end{tabular}

Diagnostic Tests

\begin{tabular}{llll}
\hline Adj. $\mathrm{R}^{2}$ & 0,98 & 0,98 & 0,99 \\
S.E. of regr. & 0,06 & 0,06 & 0,03 \\
\hline
\end{tabular}

Note: ${ }^{\text {ab, }, \mathrm{c}}$, indicate statistical significance at $1 \%$ significance level, respectively. 


\section{Discussion and Conclusion}

Technological development is critical for economic development. The literature emphasizes that technological development indicators such as R\&D expenditures, innovation, and patents significantly affect economic growth. This study investigated the impact of high-tech product exports on economic growth for Turkey over the period 1990-2019. For this purpose, Hatemi-J (2008) cointegration test with structural breaks was applied. The findings support the longterm cointegration relationship between high-tech product export and economic growth. Longterm coefficients were estimated by FMOLS, DOLS, and CCR methods. All of the test results show that high-tech exports positively impact economic growth.

Turkey and other developing countries should produce and export high-tech products to achieve sustainable growth with value-added income. However, Turkey's share of high-tech product exports seems lower than the developed and some other developing countries. For example, the share of high technology products in Turkey's exports of manufacturing industry products was $2.9 \%$ as of October 2021 (Turkstat, 2021). Therefore, Turkey should focus on product variations in export structure and promotes high-tech products that create high value-added. Also, technological capabilities in the industry need to be improved.

Turkey has created an important strategy to advance in high technology and has determined the priority areas. According to the "2023 Industry and Technology Strategy", research on some high-tech sectors will be encouraged (Turkish Ministery of Defence and Technology, 2019). These sectors are:

- High technology and innovation (strategic materials, R\&D ecosystem, technological standards, intellectual property rights).

- Digital transformation and industry (technology-oriented industry, branding, export, and industry finance).

- Entrepreneurship (increasing the entrepreneurial ecosystem and empowering entrepreneurs).

- Human capital (developing human capital, increasing R\&D talent capacity, improving software capacity).

- Infrastructure (data communication, cloud computing, cyber security, blockchain, energy, and logistics).

It is essential to produce and export high-tech products for sustainable growth. To accomplish this, Turkey may follow the following policies: i) to allocate more resources to $R \& D$ activities and increase investments in the field, ii) to improve research and development 
capabilities by increasing the quality of education for human capital, iii) to make institutional regulations to encourage and protect the innovation efforts of entrepreneurs, and finally, iv) to develop high-tech products that have high potential. All these supports may induce technological developments and high-tech product exports. Thus, the economic growth process may reach a sustainable growth structure.

Empirical findings are in accordance with the studies (e.g., Cuaresma \& Wörz 2005; Gani 2009; Arıca \& Atakl1, 2010; Kızılkaya \& Koçak, 2016; Ustabaş \& Ersin 2016; Telatar et. al., 2016; Usman, 2017; Ekananda \& Parlinggoman, 2017; Abidi, 2020). However, some studies found a negative relationship between high-tech export and economic growth (Samimi \& Alerasoul, 2009; Algan et al., 2017; Kabaklarlı et al., 2018). This study guides the researchers to examine the relationship between high-tech exports and economic growth in Turkey under structural breaks. The positive impact of high technology on economic growth is in line with economic expectations. However, it is important to determine which period there was a significant break in terms of policy proposals.

There are some limitations to the study. This study examined the effect of high technology exports on economic growth from a general point of view. A sectoral analysis examining each high-tech sub-sectors with separate data would make specific contributions to the literature. In this sense, the lack of data for each high-tech sub-sector constitutes a limitation for the study. A panel data analysis examining linear and nonlinear effects in a model with determinants of high technology will contribute to the literature. In addition, determining the specific results for each country will make the policy recommendations for the findings more meaningful.

Peer-review: Externally peer-reviewed.

Author Contributions: Conception/Design of Study- O.K., E.S.; Data Acquisition- E.K., E.S.; Data Analysis/Interpretation- E.K., O.K.; Drafting Manuscript- O.K., E.S.; Critical Revision of Manuscript- E.K., O.K.; Final Approval and Accountability- E.S., E.K., O.K. Conflict of Interest: The authors have no conflict of interest to declare.

Grant Support: The authors declared that this study has received no financial support.

\section{References}

Abidi, Y. (2020). Assessment of the contribution of high technology exports to the economic growth: The Togo Experience (2008-2017) (January 15, 2020). SSRN. Available at SSRN: https://ssrn.com/ abstract=3519921 or http://dx.doi.org/10.2139/ssrn.3519921

Aghion, P., Howitt, P., (1992). A model of growth through creative destruction. Econometrica, 60(2), 323-351.

Algan, N., Manga, M., Tekeoğlu, M. (2017). Teknolojik gelişme göstergeleri ile ekonomik büyüme arasındaki nedensellik ilişkisi: Türkiye örneği. International Conference On Eurasian Economies, 332-338.

Amaghouss, J. \& Ibourk, A. (2013), "Entrepreneurial activities, innovation and economic growth: The role of cyclical factors: Evidence from OECD countries for the period 2001-2009”, International Business Research, $6(1), 153$. 
Appiah-Otoo, I., \& Song, N. (2021). The impact of ICT on economic growth-Comparing rich and poor countries. Telecommunications Policy, 45(2), 102082.

Arıca F. \& Ataklı, R (2010). Teknolojik Gelişmenin Ekonomik Büyüme Üzerindeki Etkisi: Panel Veri Analizi, Ekonomik Yaklaşım Kongresi.

Arrow, K. (1962). Economic welfare and the allocation of resources for invention the rate and direction of inventive activity: Economic and Social Factors. Princeton University Press, pp. 609-626.

Atun, R. A., Harvey, I. \& Wild, J. (2007). Innovation, patents, and economic growth. International Journal of Innovation Management, 11(02), 279-297.

Barro, R. J. (1991). Economic growth in a cross section of countries. The Quarterly Journal of Economics, 106(2), 407-443.

Bilbao-Osorio, B. \& Rodríguez-Pose, A. (2004). From R\&D to innovation and economic growth in the E.U. Growth and Change, 35(4), 434-455.

Bilgin, C., \& Sahbaz, A. (2009). Türkiye'de büyüme ve ihracat arasındaki nedensellik ilişkileri. MPRA Papers, No:31985.

Berber, M. (2006). İktisadi büyüme ve kalkınma, Derya Kitabevi, Trabzon.

Brynjolfsson, E., Hitt, L. M., \& Yang, S. (2002). Intangible assets: Computers and organizational capital. Brookings papers on economic activity, 2002(1), 137-181.

Canbay, Ş. (2020). Investigation of the effect of Turkey's high-tech exports on the Economic growth using the structural break ARDL bounds testing. Elektronik Sosyal Bilimler Dergisi, 19(74), 865-878.

Colecchia, A. \& Schreyer, P. (2001), "The impact of Information Communications Technology on output growth", STI Working Paper, 7, OECD, Paris.

Cuaresma, J.C. \& Wörz, J. (2005). On export composition and growth. Review of World Economics, 141(1), 33-49.

Das, D.K. (1998). Changing comparative advantage and the changing composition of Asian exports. The World Economy, 21(1), 121-140.

Dickey, D. A. \& Fuller, W.A. (1981). Likelihood ratio statistics for autoregressive time series with a unit root. Econometrica: Journal of the Econometric Society, 1057-1072.

Dinçer, H., Yüksel, S., Adalı, Z., \& Aydın, R. (2019). Evaluating the role of research and development and technology investments on economic development of E7 countries. In Organizational transformation and managing innovation in the fourth industrial revolution. IGI Global, 245-263

Doruk, Ö. T. \& Söylemezoğlu, E. (2014), The Constraints of Innovation in Developing Countries: Too Many Barriers to Start Ups?, Procedia-Social and Behavioral Sciences, 150, 944-949.

Ekananda, M., \& Parlinggoman, D. J. (2017). The role of high-tech exports and of foreign direct investments (FDI) on economic growth. European Research Studies Journal, vol. 0(4A), pages 194-212.

Engle, R.F. \& Granger, C.W. (1987). Co-integration and error correction: representation, estimation, and testing. Econometrica: Journal of the Econometric Society, 251-276.

Farhadi, M. \& İsmail, R. (2011), “The impact of information and communication technology investment on economic growth in newly industrialized countries in Asia”, Australian Journal of Basic and Applied Sciences, 5(9), 508-516.

Freire-Serén, M. J. (1999). Aggregate R\&D expenditure and endogenous economic growth. Universitat Autònoma de Barcelona and Universidade de Vigo, WP 43.999

Frietsch, R., Neuhäusler, P., Jung, T. \& Van Looy, B. (2014). Patent indicators for macroeconomic growth-the value of patents estimated by export volume. Technovation, 34(9), 546-558.

Gani, A. (2009). Technological achievement, high technology exports and growth. Journal of Comparative International Management, 12(2),31-47. 
Gregory, A.W. \& Hansen,B.E. (1996). Residual-Based tests for cointegration in models with regime shifts. Journal of Econometrics, 70(1), 99-126.

Grossman, G.M. \& Helpman, E. (1989). Comparative advantage and long-run growth. The American Economic Review, 80(4), 796-815.

Grossman, G.M. \& Helpman, E. (1991). Innovation and growth in the global economy. The MIT Press.

Gülmez, A. \& Akpolat, A. G. (2014). AR-GE, İnovasyon ve Ekonomik Büyüme: Türkiye ve AB Örneği İçin Dinamik Panel Veri Analizi, Abant İzzet Baysal Üniversitesi Sosyal Bilimler Enstitüsü Dergisi, 14(2), 1-18.

Gülmez, A. \& Yardımcıŏlu, F. (2012). OECD Ülkelerinde Ar-Ge Harcamaları ve Ekonomik Büyüme İlişkisi: Panel Eşbütünleşme ve Panel Nedensellik Analizi (1990-2010), Maliye Dergisi, 163(1), 335-353.

Güloğlu, B. \& Tekin, R. B. (2012). A panel causality analysis of the relationship among research and development, innovation, and economic growth in high-income OECD countries, Eurasian Economic Review, 2(1), 32-47.

Hanel, P. (2000). R\&D, Inter-industry and international technology spillovers and total factor productivity growth of manufacturing industries in Canada 1974-1989. Economic Systems Research, 12(3), 345-361.

Hasan, I. \& Tucci, C.L. (2010). The innovation-economic growth nexus: Global evidence. Research Policy, 39(10), 1264-1276.

Hatemi-j, A. (2008). Tests for cointegration with two unknown regime shifts with an application to financial market integration. Empirical Economics, 35(3), 497-505.

Hiç, M. (1998). Büyüme ve gelişme ekonomisi. Menteş Kitabevi, İstanbul.

Hobday, M., Cawson, A. \& Kim, S.R. (2001). Governance of technology in the electronics industries of East and South-East Asia. Technovation, 21(4), 209-226.

Hu, A. G., \& Png, I. P. (2013). Patent rights and economic growth: evidence from cross-country panels of manufacturing industries. Oxford Economic Papers, 65(3), 675-698.

Inekwe, J.N. (2015). The contrubution of R\&D expenditures to economic growth in developing economies. Social Indicators Research, 124(3), 727-745.

Johansen, S. (1988). Statistical analysis of cointegration vectors. Journal of Economic Dynamics and Control, $12(2-3), 231-254$.

Johansen, S. \& Juselius, K. (1990). Maximum likelihood estimation and inference on cointegration with applications to the demand for money. Oxford Bulletin of Economics and Statistics, 52(2), 169-210.

Kabaklarl1, E., Duran, M. S., \& Üçler, Y. T. (2018). High-technology exports and economic growth: panel data analysis for selected OECD countries. In Forum Scientiae Oeconomia, 6(2), Economic Growth, Innovations and Lobbying, 47-60. Wydawnictwo Naukowe Akademii WSB.

Keynes, J. M. (1937). The general theory of employment. The quarterly journal of economics, 51(2), 209-223.

Kızılkaya, O. \& Koçak, E. (2016). Middle-Income trap and high-technology product export: an empirical investigation for upper-middle-income economies. Strategic Researches on Social Science, Editör: Ömer Kürşad Tüfekçi, Chapter 7, Lap Lambert Publishing, 125-141.

Kızılkaya, O., Sofuoğlu, E. \& Ay, A. (2017). Yüksek teknolojili ürün ihracatı üzerinde doğrudan yabancı sermaye yatırımları ve dışa açıklı̆̆ın etkisi: gelişmekte olan ülkelerde panel veri analizi. Doğuş Üniversitesi Dergisi, 18(1), 63-78.

Krugman, P. R. (2000). Technology, trade and factor prices. Journal of international Economics, 50(1), 51-71.

Kula, F. (2003). Yatırım-Gelişme yolu yaklaşımı: Teori ve Türkiye üzerine ampirik gözlemler. Atatürk Üniversitesi İktisadi ve İdari Bilimler Dergisi, 17, 3-4.

Lee, J. V. (2011). Emprical Evidence of Causalty Between Information Communication Technology and Economic Growth in China, Japan and South Korea, The 11th International DSI ant the 16th APDSI Joint Meeting, 12-16 July, Taipei, Taiwan, 1-7. 
Lichtenberg, F. R. (1992). R\&D investment and international productivity differences, National Bureau of Economic Research.

Liu, W.H. \& Lin, Y.C. (2005). Foreign patent rights and high-tech exports: evidence from Taiwan. Applied Economics, 37(13), 1543-1555.

Liu, C., \& Xia, G. (2018). Research on the dynamic interrelationship among R\&D investment, technological innovation, and economic growth in China. Sustainability, 10(11), 4260.

Lucas, E. (1988). On the mechanics of economic development. Journal of Monetary Economics, 22(1), 3-42.

Marx, K. (1867), Capital: A critique of political economy 1.

McCann, F. (2007). Export composition and growth. University College Dublin.

Montalvo, J.G. (1995). Comparing cointegrating regression estimators: some additional monte carlo results. Economics letters, 48(3-4), 229-234.

Myszczyszyn, J. (2020). The Long-run Relationships between Number of Patents and Economic Growth. European Research Studies, 23(3), 548-563.

Nair, M., Pradhan, R. P., \& Arvin, M. B. (2020). Endogenous dynamics between R\&D, ICT and economic growth: Empirical evidence from the OECD countries. Technology in Society, 62, 101315.

Oliner, S.D., Sichel, D.E., Triplett, J.E. \& Gordon, R.J. (1994). Computers and output growth revisited: how big is the puzzle. Brookings Papers on Economic Activity, 2, 273-334.

Park, J.Y. (1992). Canonical cointegrating regressions. Econometrica: Journal of The Econometric Society, 119143.

Pazarlığlu, M. V. \& Gürler, Ö. K. (2007). Telekomünikasyon yatırımları ve ekonomik büyüme: panel veri yaklaşımı, Finans Politik ve Ekonomik Yorumlar, 44(508), 35-43.

Phillips, P.C., Hansen, B.E. (1990). Statistical inference in instrumental variables regression with i (1) processes. The Review of Economic Studies, 57(1), 99-125.

Phillips, P.C.B. \& Perron, P. (1988). Testing for a unit root in time series regression. Biometrika, 335-346.

Pohjola, M. (2000). Information Technology and Economic Growth, A Cross-Country Analysis, 173.

Ricardo, D. (1817). On the Principles of Political Economy and Taxation: London.

Posner, M. V. (1961). International trade and technical change. Oxford Economic Papers, 13(3), 323-341.

Romer, P.M. (1986). Increasing returns and long-run growth. The Journal of Political Economy, 94(5), 1002-1037.

Romer, P.M. (1990). Endogenous technological change. The Journal of Political Economy, 98(5), 71-102.

Romer, P. M. (1994). The origins of endogenous growth. Journal of Economic Perspectives, 8(1), 3-22.

Samimi, A. J. (2010). ICT and Economic Growth: New Evidence from Some Developing Countries, Australian Jorunal of Basic and Applied Sciences, 4(8): 3086-3091.

Samimi, A. J. \& Alerasoul, S. M. (2009). R\&D and economic growth: New evidence from some developing countries, Australian Journal of Basic and Applied Sciences, 3(4), 3464-3469.

Schumpeter, J. (1966). Invention and economic growth.

Smith, A. (1776), An Inquiry into the Nature and Causes of the Wealth of Nations, Methuen.

Solow, R.M. (1956). A contribution to the theory of economic growth. The Quarterly Journal of Economics, 70(1), 65-94.

Stock, J.H. \& Watson, M.W. (1993). A simple estimator of cointegrating vectors in higher order integrated systems. Econometrica: Journal of the Econometric Society, 783-820.

Sylwester, K. (2001). R\&D and economic growth. Knowledge, Technology \& Policy, 13(4), 71-84. 
Şahin, B. E. (2019). Impact of high technology export on economic growth: An analysis on Turkey. Journal of Business Economics and Finance, 8(3), 165-172.

Taban, S. (2011). İktisadi büyüme, kavram ve modeller. Nobel Yayınevi, Ankara.

Telatar, O.M., Değer, M.K. \& Doğanay, M.A. (2016). Teknoloji yoğunluklu ürün ihracatının ekonomik büyümeye etkisi: Türkiye örneği (1996: q1-2015: q3). Atatürk Üniversitesi İktisadi ve İdari Bilimler Dergisi, 30(4), 921933.

Tiryakioğlu, M. (2011). Teknoloji transferi, teknoloji yoksulluğu mu?. Ankara Üniversitesi SBF Dergisi, 66(02), 169-199.

The World Bank (2014). Trading up to the high income. https://www.worldbank.org/content/dam/Worldbank/ document/eca/turkey/tr-cem-trade-eng.pdf (Access Date [21.10.2021]

The World Bank (2018). World development indicators, http://databank.worldbank.org/data/reports. aspx? source=world-development-indicators Access Date [14.02.2020].

The World Bank (2021). High-technology exports. https://data.worldbank.org/indicator/TX.VAL.TECH.CD [Access Date: 03.06.2021].

Turkish Ministry of Industry and Technology (2019). 2023 Sanayi ve Teknoloji Stratejisi. https://www.sanayi.gov. tr/assets/pdf/SanayiStratejiBelgesi2023.pdf (Access Date [22.12.2021]

Turkstat (2021). Foreign Trade Statistics (January-October 2021). https://data.tuik.gov.tr/Bulten/Index?p=DisTicaret-Istatistikleri-Ekim-2021-37422 Access Date [17.12.2021]

Usman, M. (2017). Impact of high-tech exports on economic growth: empirical evidence from pakistan. Journal on Innovation and Sustainability, 8(1), 75-89.

Ustabaş, A. \& Ersin, Ö. (2016). The effects of R\&D and high technology exports on economic growth: a comparative cointegration analysis for Turkey and South Korea. In International Conference On Eurasian Economies, 44-55.

Wakelin, K. (2001). Productivity growth and R\&D expenditure in UK manufacturing firms. Research Policy, 30(7), 1079-1090.

Vernon, R. (1966). International trade and international investment in the product cycle. Quarterly journal of economics, 80(2), 190-207.

Vu, K. M. (2013). Information and communication technology (ICT) and Singapore's economic growth. Information Economics and Policy, 25 (4), 284-300.

Yeldan, E. (2010). İktisadi büyüme ve bölüşüm teorileri. Efil Yayınevi, Ankara.

Zachariadis, M. (2004). R\&D-induced Growth in the OECD?. Review of Development Economics, 8(3), 423-439. 
